\title{
SOD3 wt Allele
}

National Cancer Institute

\section{Source}

National Cancer Institute. SOD3 wt Allele. NCI Thesaurus. Code C123148.

Human SOD3 wild-type allele is located in the vicinity of 4 p15.2 and is approximately 11

$\mathrm{kb}$ in length. This allele, which encodes extracellular superoxide dismutase [Cu-Zn]

protein, is involved in the detoxification of superoxides. 